Egyptian Journal of Aquatic Biology \& Fisheries

Zoology Department, Faculty of Science,

Ain Shams University, Cairo, Egypt.

ISSN $1110-6131$

Vol. 26(1): 299 - 311 (2022)

www.ejabf.journals.ekb.eg

\title{
Isolation and Identification of Pathogenic Bacterial Flora from Native Freshwater
} Fish of Kashmir Himalaya

\section{Umer Aziz Mir $^{1 *}$, Fayaz Ahmad ${ }^{1,2}$, Ibraq Khurshid ${ }^{3}$ and Rasy Fayaz Choh Wani ${ }^{1}$}

1-Advance Research Laboratory, Department of Zoology, University of Kashmir, Hazratbal, Srinagar - 190006 Jammu and Kashmir, India.

2-Department of Environmental Sciences, University of Kashmir, Hazratbal, Srinagar - 190006

Jammu and Kashmir, India.

3-Department of Zoology, Central University of Kashmir, Ganderbal, Jammu \& Kashmir, India. *Corresponding Author: mirumer963@gmail.com

\section{ARTICLE INFO} Article History:

Received: Feb. 4, 2021

Accepted: Dec. 23, 2021

Online: Jan. 19, 2022

Keywords:

Bacteria,

Identification,

Indicator,

Schizothorax esocinus,

River Jhelum

\begin{abstract}
Identification of freshwater fish's bacterial flora is an important tool for the determination of quality and the safety of human consumption. The aim of the present study was to isolate the bacterial flora of freshwater fish from gills, buccal cavity and skin surface of Schizothorax esocinus, from the locations of river Jhelum of Kashmir valley. A total number of 45 samples of freshwater fish were selected on the basis of clinical diagnosis. The fish sample was distributed on the basis of clinical inspection as gills [20\%, $(n=9)]$, skin [11.11\%, $(n=5)]$, gills and skin [24.44\%, $(n=11)]$, gills and buccal cavity $[13.33 \%,(n=6)]$, skin and buccal cavity $[8.90 \%,(n=4)]$, gills, skin and buccal cavity [22.22\%, $(\mathrm{n}=10)]$, respectively. Statistically, the frequency distribution was not uniform and $\mathrm{p}<0.5$. Freshwater fish's bacterial flora consists of Pseudomonas aeruginosa, Staphylococcus sp., Enterococcus sp., Bacillus sp., Salmonella sp. and Escherichia coli. The isolation of bacterial flora in fish serves as an indicator organism of anthropogenic pressures/activities of the aquatic environment. Their presence causes diseases for humans. The association of pathogenic bacterial species in fish may lead to food safety hazards for the consumers if the fish are handled or prepared improperly.
\end{abstract}

\section{INTRODUCTION}

Over the last 60 years, global fish production has significantly increased, reaching roughly 179 million tonnes in 2018 with a value of $\$ 401$ billion (FAO, 2020). Global fish consumption has also increased, from $9.0 \mathrm{~kg}$ per capita in 1961 to $20.5 \mathrm{~kg}$ in 2018 . Globally, $88 \%$ of fish output is for human nutrition, with $44 \%$ in the form of live, fresh, or cold fish, the most desirable and expensive forms in many markets (FAO, 2020). The remainder of the production is processed, with $35 \%$ frozen, $11 \%$ prepared and preserved, 
and $10 \%$ dried, salted, smoked or otherwise cured (FAO, 2020). Because finfish account for more than $65 \%$ of total global food fish output, $76.5 \%$ of domestic landings in the US were consumed fresh and frozen, $1.9 \%$ canned, and 1.5\% cured (NOAA, 2020). Global aquaculture production is expected to triple by 2050 due to the increased demand on high-quality protein, reduced wild fish harvest, and technological breakthroughs in fish farming (Ibrahim et al., 2020).

India is globally the second largest producer of fish, as well as fresh water fish. With a total population of 2,80,63,537 fishmen (1,56,65,630 males and 1,23,97,907 females), fish production reached 141.64 lakh tonnes (37.27 lakh tonnes for marine and 104.37 lakh tonnes for inland fisheries) in 2019-20, up from 107.62 lakh tonnes (36 lakh tonnes for marine and 71.62 lakh tonnes for inland fisheries) in 2015-2016 (Department of Fisheries, Govt. of India, 2020). India's share of global fish production has steadily increased, from around 11.4\% in 2016 to 13.5\% in 2018 (Department of Fisheries, Govt. of India, 2020).

Fish are among the best sources of protein specified for human consumption; however, fish products may carry the spoilage, pathogenic and opportunistic pathogenic microorganisms, including the food borne pathogens (FAO, 2000). Fish consumers are vulnerable to risky effects caused by those pathogens (Huss, 1997; Davies et al., 2001; Rohde $\boldsymbol{e t}$ al., 2015). Fishes engage in complex energy and material transferring processes in a wide range of trophic and symbiotic interactions, while they also serve as reservoirs and vectors of microorganisms (Parris et al., 2016; Ngugi et al., 2017). Such diversity makes fish communities useful for exploring the factors shaping animal associated microbiomes (Lescak \& Milligan-Myhre, 2017). Gills are the primary spots for gas and waste exchanges in fish, adding to mucosal immune interactions, osmoregulation and detoxification (Maina, 2002). In addition, gill microflora may play significant roles in overall fish health and physiology.

Animal-associated microflora often contain hundreds of bacterial or archaeal species, many of which are hypothesized to contribute to host health, behavior and development (Cantley \& Clardy, 2015; Gilbert et al., 2020). Microbes, on the other hand, live in a variety of niches throughout the animal body, including associations with non-GI mucosal surfaces, which also participate in chemical or gas exchange as well as as barriers or entry points for pathogens. Characterization of non-GI mucosal microbiomes, such as those of the gills, lungs, and skin is therefore critical for identifying novel activities of animal-associated microflora and understanding the link between ambient and host microbial communities.

The mucosal surface of the gills of fish may also be a very unusual environment for host-associated bacteria. In contrast to the GI tract, where oxygen may be more limiting and the genetic capacity for anaerobic fermentative metabolism has been proven, the fish 
gill is potentially influenced by high local concentrations of oxygen and nutrients (Wilkie, 2002; Ngugi et al., 2017). Furthermore, the gills may experience high levels of mucosal discharge, particularly during stressful conditions (Hess et al., 2015). Furthermore, gills may have high connectivity with the surrounding water microbiome as well as between the water and the bloodstream (Maina, 2002) and may act as crucial entry points for pathogens (Hess $\boldsymbol{e t}$ al., 2015). Consequently, to make a decision regarding the safety of fish consumption, it is important to identify and characterize the fish bacterial flora. Fishing for consumption is very common in Jammu \& Kashmir, but the microbiological assessment of freshwater fish caught in rivers and lakes have not yet been determined. Therefore, the aim of this study was to detect the bacterial flora of Schizothorax esocinus fish caught by the local fishermen.

\section{MATERIALS AND METHODS}

\section{Chemicals, equipments and glassware}

Nutrient agar (NA; supplemented with crystal violet and methyl red), Nutrient Broth medium, MacConky agar (MA) medium, High chrome medium, Blood agar Xylose lysine deoxycholate agar (XLD) medium, and Thiosulphate citrate-bile salts sucrose agar (TCBS) medium, glycerol, and ethanol were used in the present experiment. All chemicals and reagents were acquired from Merck and Sigma Aldrich (Germany), and Sigma Aldrich (Switzerland). $37^{\circ} \mathrm{C}$ incubator, $37^{\circ} \mathrm{C}$ shaker, hot air oven, laminar flow, analytical balance, digital weighing machine, Vortex shaker and steam sterilizer (autoclave) were all used.

\section{Collection of fish samples}

The current study estimates the bacterial flora of indigenous cold water species Schizothorax esocinus belonging to family Cyprinidae and order Cypriniformes. The samples of S. esocinus were collected from the locations of River Jhelum of Kashmir valley with the help of some fishermen and were identified by various taxonomic keys (Tilak, 1987; Jhingram, 2007). After collection, the signs and symptoms related to infected fish were recorded. The fish samples were collected aseptically, labelled and immediately transported in a sterile container to the Advance Research laboratory and Parasitology laboratory, Department of Zoology, University of Kashmir - Hazratbal, Srinagar, Jammu and Kashmir. The sampled fish were then processed within 2- 4 hours.

\section{Sampling}

Swabs of skin and buccal cavity were taken for analysis. Each fish was swabbed from skin and buccal cavity and inoculated on Nutrient Agar, TSA, MacConkey agar and Blood agar (Spanggaard et al., 2000; Dar et al., 2013; Dar et al., 2015). Then, they 
were incubated at $37^{\circ} \mathrm{C}$ for 24 hours (Eddy \& Jones, 2002; Al-Harbi \& Uddin, 2004, 2005).

The gills were cut with sterile scissors under aseptic condition and then processed individually (Fig. 1.). The gill samples were placed in $0.85 \%$ sodium chloride (saline water) solution, and 1 gram of gill sample was crushed with the help of a homogenizer with about 10 $\mathrm{ml}$ of sterilized pre-chilled saline water, and the stock solution were serially diluted.

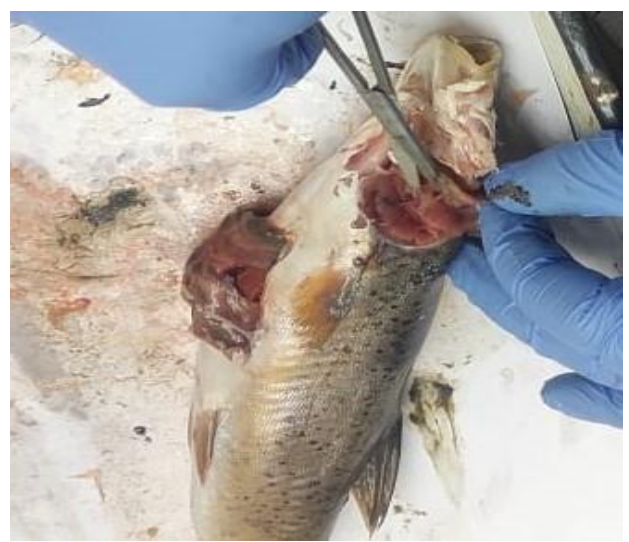

Fig. 1. Dissection of gill tissue

The gills homogenate was used as inoculum; samples were separately analyzed by ensuring homogeneity using a sterile pipette. An amount of $1 \mathrm{~mL}$ of each sample was suspended into $9 \mathrm{~mL}$ sterile saline water aseptically, and the outcome was then shaken together in a vortex shaker. Further serial dilution of 10 -folds was carried out. An amount of $100 \mu 1$ of serially diluted homogenized samples were spread on duplicate sterilized culture media Nutrient Agar, TSA, MacConkey agar and Blood agar plates and incubated at $37^{\circ} \mathrm{C}$ for 24 hours. Colonies with different morphological appearances were isolated. Purity of the isolates were determined by streaking separately on culture media plates. Cultures were maintained and stored at $4^{\circ} \mathrm{C}$ (Ghosh et al., 2002).

\section{Identification of bacteria}

After isolation, phenotypic characteristics (colonial morphology, microscopic appearance), staining technique (Gram's Staining), and biochemical tests were performed for the identification of available bacterial identification keys described in the studies of Cruickshank et al. (1979), Collins et al. (1994), Cheesbrough (2006) and Mondal et al. (2010).

Pure cultures of the isolates were identified using biochemical characterisation using the criteria outlined in Bergey's Manual of Determinative Bacteriology (Garrity, 2001). In addition, the analytical profile index of the API20-E system was used to confirm each strain (Buller, 2004). 


\section{RESULTS}

\section{Sign and symptoms of infected fish}

Fish samples were collected from the locations of River Jhelum in Kashmir valley. Some signs and symptoms were observed, such as hemorrhaging of skin and internal organs, bulging eyes, swollen abdomens, reddish tints/spots to eyes, gills, skin, and fins and abnormal behavior, respectively.

\section{Isolation and identification of bacteria}

Table (1) represents the number of fish samples per area, from where the isolation of the bacterial species were taken, including gills [20\%, $(n=9)]$, skin [11.11\%, $(n=5)]$, gills and skin [24.44\%, $(\mathrm{n}=11)]$, gills and buccal cavity [13.33\%, $(\mathrm{n}=6)]$, skin and buccal cavity $[8.90 \%,(\mathrm{n}=4)]$, gills, skin and buccal cavity [22.22\%, $(\mathrm{n}=10)]$, respectively. Statistically, the frequency distribution was not uniform and $\mathrm{p}<0.5$.

The various types of selective, enriched and differential media were used for the isolation of pure colonies of bacterial species. Methyl red and crystal violet indicators were practiced for the screening of Gram-negative bacteria in comparison to Grampositive bacteria (Fig. 2). It was witnessed that all isolated species showed growth on types of medium used. Five bacteria species were isolated and identified, such as Staphylococcus sp., Enterobacter sp., Pseudomonas sp., Bacillus sp., Escherichia coli and Salmonella sp. (Table $2 \&$ Fig. 3).

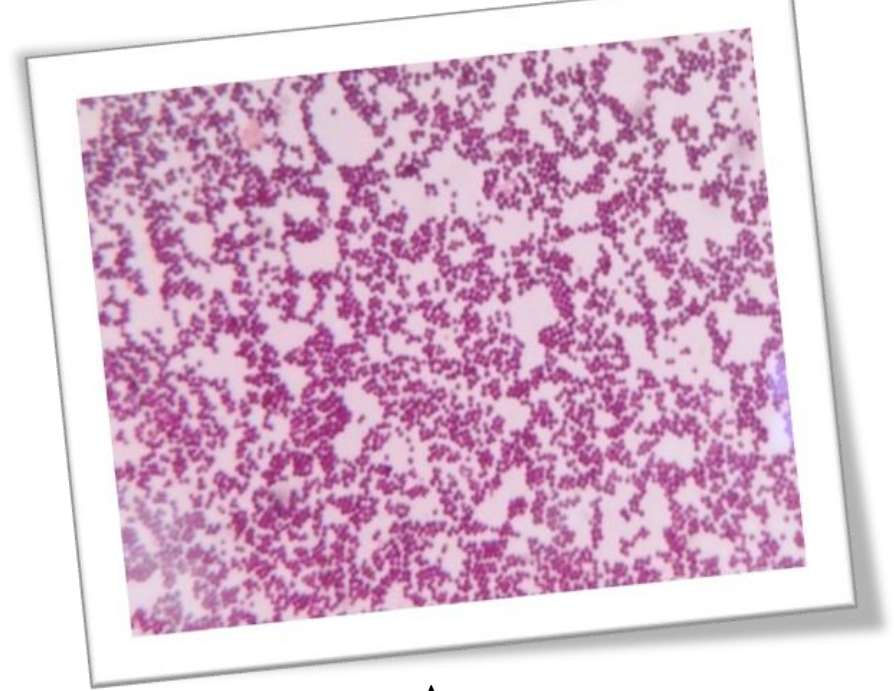

A

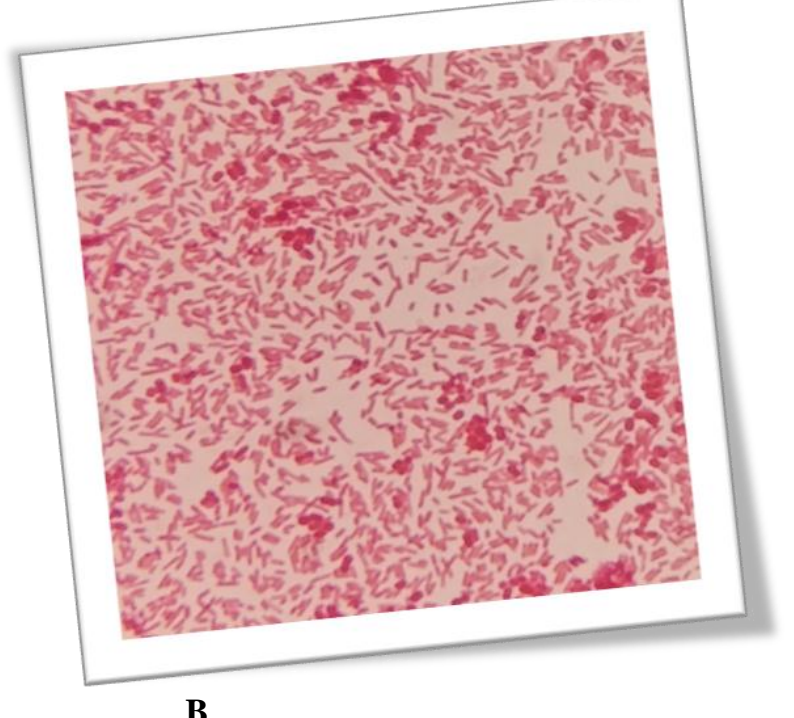

B

Fig. 2. (A) Gram-positive cocci and (B) Gram- negative bacilli 


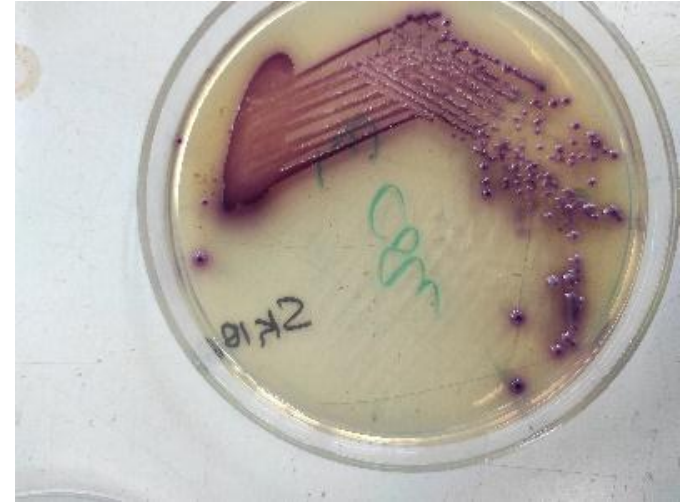

Escherichia coli

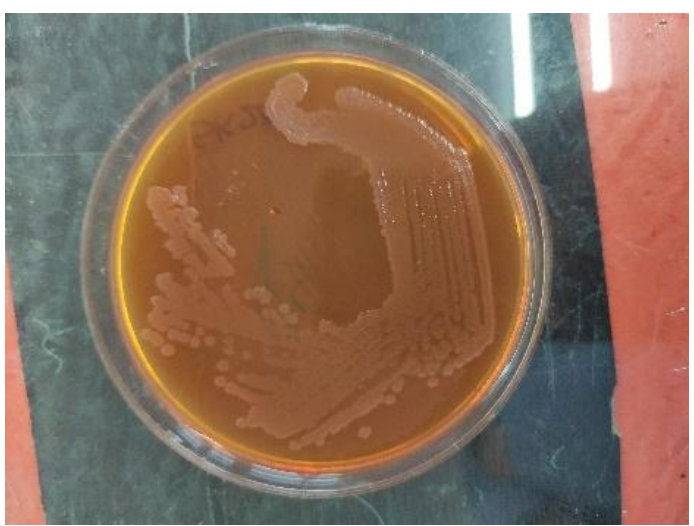

Pseudomonas sp.

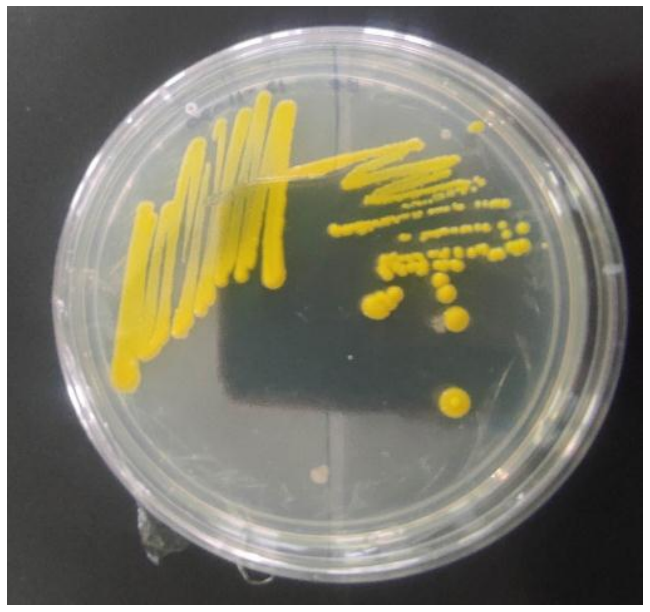

Bacillus sp.

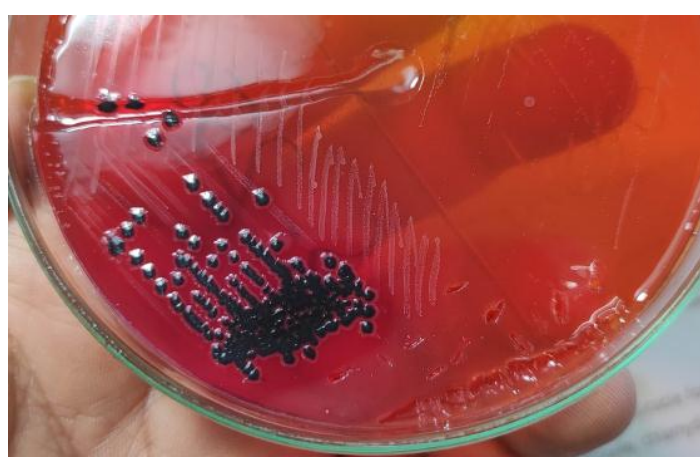

Salmonella sp.

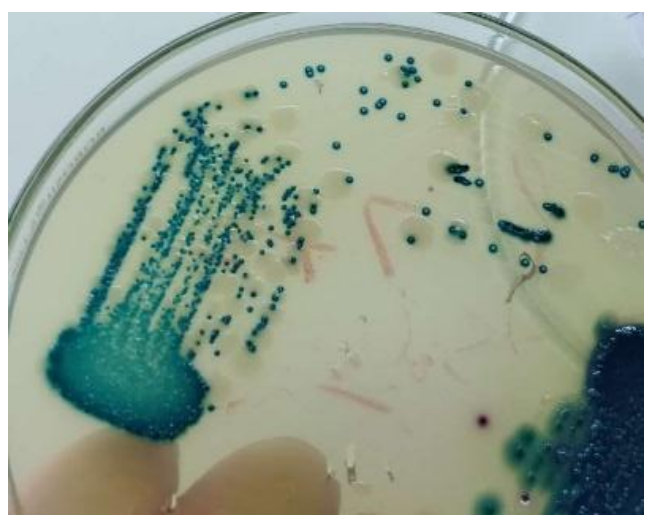

Enterobacter sp.

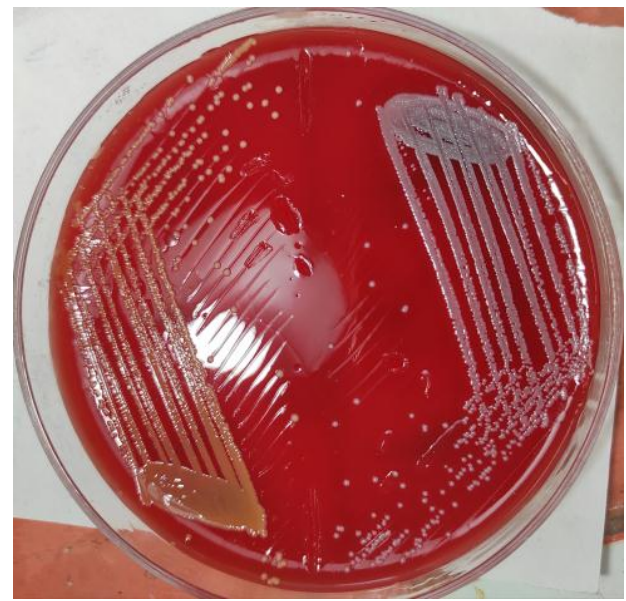

Staphylococcus spp.

Fig. 3. Pure culture of bacterial species on different media 
Table 1. The percentage distribution of fish samples on basis of diagnosis

\begin{tabular}{|c|c|c|c|c|}
\hline Area & Frequency $(\mathbf{N})$ & Percentage (\%) & Chi Square & $P$-value \\
\hline Gills & 9 & 20.00 & \multirow{7}{*}{5.533} & \multirow{7}{*}{$p<0.5$} \\
\hline Skin & 5 & 11.11 & & \\
\hline Gills, Skin & 11 & 24.44 & & \\
\hline Gills, Buccal Cavity & 6 & 13.33 & & \\
\hline Skin, Buccal Cavity & 4 & 8.90 & & \\
\hline Gills, Skin, Buccal Cavity & 10 & 22.22 & & \\
\hline Total & 45 & 100 & & \\
\hline
\end{tabular}

Table 2. Biochemical tests for the identification of fish associated bacterial flora $\mathrm{GNB}=$ Gram negative bacilli, GPC $=$ Gram positive cocci $;(+)=$ Positive $;(-)=$ Negative .

\begin{tabular}{|l|c|c|c|c|c|c|}
\hline $\begin{array}{c}\text { Biochemical } \\
\text { Tests }\end{array}$ & $\begin{array}{c}\text { Enterobacter } \\
\text { sp. }\end{array}$ & $\begin{array}{c}\text { Escherichia } \\
\text { coli }\end{array}$ & $\begin{array}{c}\text { Pseudomonas } \\
\text { Aeruginosa }\end{array}$ & $\begin{array}{c}\text { Bacillus } \\
\text { sp. }\end{array}$ & $\begin{array}{c}\text { Salmonella } \\
\text { sp. }\end{array}$ & $\begin{array}{c}\text { Staphylococcus } \\
\text { spp. }\end{array}$ \\
\hline $\begin{array}{l}\text { Gram } \\
\text { Reaction }\end{array}$ & GNB & GNB & GNB & GPC & GNB & GPC \\
\hline Catalase test & + & + & + & + & + & + \\
\hline Citrate test & + & - & + & + & + & - \\
\hline $\begin{array}{l}\text { Indole test } \\
\text { Methyl red } \\
\text { Test }\end{array}$ & - & + & - & - & - & - \\
\hline Oxidase test & - & + & - & - & + & - \\
\hline Urease test & - & - & + & - & - & + \\
\hline Motility test & + & + & + & + & + & + \\
\hline $\begin{array}{l}\text { Carbohydrat } \\
\text { e } \\
\text { Voges } \\
\text { proskeur test }\end{array}$ & + & + & + & + & + & + \\
\hline
\end{tabular}




\section{DISCUSSION}

Microflora is a significant part of the aquatic ecosystem, and the interaction between the pathogenic microflora and this aquatic environment result in the contagious diseases in aquaculture methods (Noga, 2000; Ikpi \& Offem, 2011). The occurrence of the pathogenic bacterial species cause the contamination of the aquatic water bodies originated from animal wastes (Abdelhamid et al., 2006). The isolation of E. coli, shigella and salmonella from the fishes indicates the presence of contamination by fecal matter, which pollutes the environment (Yagoub et al., 2009). The prevalence of Staphylococcus aureus has public health significance for it has been incriminated with food-borne intoxication and infection. Its ability to produce enzymes and toxins is responsible for this effect (Umoh \& Odoba, 1999).

The aquaculture sectors are prone to several diseases, increasing the vulnerability to pathogenic infections (El -Sayed, 2006). In addition, the dispersion of mobile Aeromonas spp. in the aquatic environment and fish has been documented (Kaper et al., 1981; Abeyta et al., 1986; Hatha et al., 2005; Hussain et al., 2014). Similarly, Noor El Deen et al. (2014) discovered that skin ulcers could be the source of infection produced by Aeromonas spp. The findings are consistent with those of Hazen et al. (2012) who suggested that, the colour of a bacterial colony may be utilized to establish its genus level. Aeromonas spp. is an opportunistic pathogen that can be found in freshwater habitats around the world, as well as in soil, water and food. This bacterium can cause foodborne and nosocomial diseases (Cabral, 2010; Janda, 2010; Gauthier, 2015).

In this study, five bacteria species were detected from the gills, skin, and buccal cavity of S. esocinus. Among the isolated bacteria, six bacterial species were identified, such as Staphylococcus sp., Enterobacter sp., Pseudomonas aeruginosa, Bacillus sp. Escherichia coli and Salmonella sp. This result coincides with the findings of Ahmed and Naim (2002) who postulated that, bacteria isolated from brackish pond water, sediments, and healthy tilapia farmed in Saudi Arabia were largely Gram-negative; a result that matches with the present findings. Some marine fish species showed septicemic bacterial infections, including vibrios, aeromonads, pseudomonads, photobacteria, streptococci, and staphylococci during various stages of development (Alicia et al., 2005; Samuelsson et al., 2006).

The organism may contaminate the smoked fish through human handlers. Its survival may be related to its ability to survive at high salt levels. It can grow well at temperatures of $30-37^{\circ} \mathrm{C}$ (Brown, 2004). The presence of Bacillus and Salmonella species are also important, since they may result in food borne illnesses. The presence of Salmonella sp. indicates poor food preparation and handling practices such as cross contamination. Most of the isolated organisms are probably contaminants, specifically after the smoking operation, and they are mostly spoilage organisms. 
Nevertheless, potentially pathogenic organisms, isolated from smoked fish, showed the need for proper hygienic conditions for the processing and distribution of products. Brown (2004) noted that the selling of smoked fish on wooden or metal tables on open quay-sides increases the several potential bacteriological dangers, and the more or less lengthy the exposure to increasing temperature is, the more spoilage bacteria are permitted to multiply.

The presence of the enteric bacteria in fishes serves as an indicator of fecal contamination and water pollution. The association of pathogenic bacteria in fish suggested that, if fish were not properly handled or prepared, food safety with respect to consumers would be prone to hazards (Akila \& Kumaran, 2018). During this study, the fish samples sheltered human disease-causing organisms, among which food poisoning, diarrhea, typhoid, fever etc are considered. The micro-organisms such as Pseudomonas, Salmonella, S. aureus and shigella are present in food material, causing most foodborne diseases, considering the environment and consumers. Sujatha et al. (2011) reported the same type of human pathogenic bacteria in two edible fishes, Priacanthus hamrur and Megalaspis cordyla at Royapuram of Chennai, India. Moreover, Akila and Kumaran (2018) reported the same types of pathogenic species during their study, which are very harmful to the human population.

\section{CONCLUSION}

The present study concluded that water of the River Jhelum was contaminated due the anthropogenic activities. Different bacterial strains were isolated from a fish association, which exhibit satisfactory microbiological quality. These bacteria cause a serious threat to fishes and their consumers as well. The Pseudomonas sp. and Staphylococcus sp. were mostly present, causing rapid fish deterioration. The dominance of this group indicates that the fish are prone to spoilage processes.

\section{ACKNOWLEDGEMENT}

Authors are highly thankful to the Head of the Department of Zoology, University of Kashmir, and also the Head of the Department of Microbiology, SKIMS Srinagar Kashmir, India for accessing the laboratory facilities to carry out the present work. The authors also direct their thanks to the fishing community of River Jhelum for their cooperation. 


\section{REFERENCES}

Abdelhamid, A. M.; Gawish, M. M. and Soryal, K. A. (2006). Comparative study between desert cultivated and natural fisheries of mullet fish in Egypt, IImicrobiological concern. J. Agric. Sci. Mansoura Univ, 31:5681-5687.

Abeyta, C.; Kaysner, C.A.; Wekell, M. M.; Sullivan, J. J. and Stelma, G.N. (1986). Recovery of Aeromonas hydrophila from oysters implicated in an outbreak of food borne illness. J.F.P., 49:643- 646.

Ahmed, H.; Atarbi, Al. and Naim U. (2002). Bacteria diversity of tilapia cultured in brackish water in Saudi Arabia. Aquaculture, 250:566-572.

Akila, N. and Kumaran, R.S. (2018) Isolation and Identification of prevalent bacterial pathogens from an exotic fish Tilapia zillii and Oreochromis mossambicus. International journal of green pharmacy:12(3):S497.

Al-Harbi, A. H. and Uddin, M. N. (2004). Seasonal variation in the intestinal bacterial flora of hybrid tilapia (Oreochromis niloticus $\times$ Oreochromis aureus) cultured in earthen ponds in Saudi Arabia. Aquaculture, 229(1-4): 37-44.

Al-Harbi, A. H. and Uddin, M. N. (2005). Bacterial diversity of tilapia (Oreochromis niloticus) cultured in brackish water in Saudi Arabia. Aquaculture, 250(3-4):566-572.

Alicia, E.; Toranzo, T.; Magarinos, B. \& Romalde, J. L. (2005): A review of the main bacterial fish diseases in mariculture systems. Aquac., 246: 37-61.

Brown, G. E. (2004). A Report on the Prevalence of Bacteria specie in Retailed Smoked Fish within Bauchi Metropolis.

Cantley, A. M. and Clardy, J. (2015). Animals in a bacterial world: opportunities for chemical ecology. Natural product reports, 32(7):888-892.

Cheesbrough, M. (2006). District Laboratory Practice in Tropical Countries (2nd Edition). London English Language Book Society. pp:100-194.

Cruikshank, J.; Gawler, A. H. and Shaldon, C. (1979). Oerskovia species: rare opportunistic pathogens (Plate XLI). Journal of medical microbiology, 12(4):513515.

Ibrahim, M., Ahmad, F., Yaqub, B., Ramzan, A., Imran, A., Afzaal, M., Mirza, S.A., Mazhar, I., Younus, M., Akram, Q. and Taseer, M.S.A. (2020). Current trends of antimicrobials used in food animals and aquaculture. In Antibiotics and antimicrobial resistance genes in the environment (pp. 39-69). Elsevier

Davies, A. R.; Capell, C.; Jehanno, D.; Nychas, G. J. and Kirby, R. M. (2001). Incidence of foodborne pathogens on European fish. Food control, 12(2):67-71.

Eddy, S. D. and Jones, S. H. (2002). Microbiology of summer flounder Paralichthys dentatus fingerling production at a marine fish hatchery. Aquaculture, 211(1-4), 9-28. 
El-Sayed, A.F.M. (2006). Stress and diseases. 149-151. In: Tilapia Culture (El Sayed, A.F.M. ed.), CABI Publishing, Cambridge.

Food and Agriculture Org. Agriculture Organization of the United Nations. Fisheries Department. (2000). The State of World Fisheries and Aquaculture, 2000 (Vol. 3).

Fisheries Statistics Division Department of Fisheries Ministry of Fisheries, Animal Husbandry \& Dairying Government of India 2020.

Food and Agriculture Organization (FAO). (2020). The state of world fisheries and aquaculture 2020. Retrieved from http://www.fao. org/state-of-fisheries-aquaculture Garrity, G.M. (2001): Bergey's manual of systematic bacteriology. New York: Springer Verlag.

Ghosh, K.; Sen, S. K. and Ray, A. K. (2002). Characterization of Bacilli isolated from the gut of rohu, Labeo rohita, fingerlings and its significance in digestion. Journal of Applied Aquaculture, 12(3):33-42.

Hatha. M., Vivekanandhan, A.A. and Christol G.J.J. (2005). Antiobiotic resistance pattern of motile aeromonads from farm raised fresh water fish. I.J.F.M., 98:131-134.

Hazen, T.C.; Fliermans, C.B.; Hirsch, R.P.; Esch, G.W.; Da Cruz, S.P.C.; Neto, J.G.M. and De, F.R. (1978). Prevalence and distribution of Aeromonas hydrophila in the United States. A.E.M., 36:731-738.

Hess, S.; Wenger, A. S.; Ainsworth, T. D. and Rummer, J. L. (2015). Exposure of clownfish larvae to suspended sediment levels found on the Great Barrier Reef: impacts on gill structure and microbiome. Scientific reports, 5:10561.

Hussain, I.A.; Jeyasekaran, G.; Shakila, R.J.; Raj, K.T. and Jeevithan, E. (2014) Detection of hemolytic strains of Aeromonas hydrophila and A. sobria along with other Aeromonas spp. from fish and fishery products by multiplex PCR. J.F.S.T., 51(2):401-407.

Huss-Danell, K. (1997). Tansley Review No. 93. Actinorhizal symbioses and their N 2 fixation. New Phytologist:375-405.

Ikpi, G. and Offem, B. (2011). Bacterial infection of mudfish Clarias gariepinus (Siluriformes: Clariidae) fingerlings in tropical nursery ponds. Revista de biologia tropical, 59(2):751-759.

Janda, J. M. and Sharon, L. A. (2010) The genus Aeromonas: taxonomy, pathogenicity, and infection. C.M., reviews, Vol. 23(1):p. 35-73.

Jha, G. N.; Dar, B. A.; Jha, T.; Sarma, D.; and Qureshi, T. A. (2013). Effect of spirulina and apple peel meal on growth performance, body composition and total carotenoids of snow trout (Schizothorax richardsonii). Indian J. Anim. Nutr, 30(4):404-409.

Jhingran, V.G. (2007). Fish and Fisheries of India. $3^{\text {rd }}$ edn. Hindustan Publishing Corporation, New Delhi, India:727 pp 
Kaper, J.B.; Lockman, H.; Colwell, R.R. and Joseph, S.W. (1981). Aeromonas hydrophila: ecology and toxigenicity of isolates from an estuary. J.A.B., 50:359-377. Lescak, E. A. and Milligan-Myhre, K. C. (2017). Teleosts as model organisms to understand host-microbe interactions. Journal of bacteriology, 199(15).

Maina, J. G.; Beames, R. M.; Higgs, D.; Mbugua, P. N.; Iwama, G. and Kisia, S. M. (2002). Digestibility and feeding value of some feed ingredients fed to tilapia Oreochromis niloticus (L.). Aquaculture Research, 33(11):853-862.

Mehmood, B.; Dar, K. K.; Ali, S.; Awan, U. A.; Nayyer, A. Q.; Ghous, T. and Andleeb, S. (2015). In vitro assessment of antioxidant, antibacterial and phytochemical analysis of peel of Citrus sinensis. Pakistan journal of pharmaceutical sciences, 28(1).

Mondal, S.; Roy, T. and Ray, A. K. (2010). Characterization and identification of enzyme- producing bacteria isolated from the digestive tract of bata, Labeo bata. Journal of the World Aquaculture Society, 41(3):369-377.

Ngugi, C. C.; Oyoo- Okoth, E. and Muchiri, M. (2017). Effects of dietary levels of essential oil (EO) extract from bitter lemon (Citrus limon) fruit peels on growth, biochemical, haemato- immunological parameters and disease resistance in Juvenile Labeo victorianus fingerlings challenged with Aeromonas hydrophila. Aquaculture Research, 48(5):2253-2265.

Ngugi, D. K.; Miyake, S.; Cahill, M.; Vinu, M.; Hackmann, T. J.; Blom, J. and Stingl, U. (2017). Genomic diversification of giant enteric symbionts reflects host dietary lifestyles. Proceedings of the National Academy of Sciences, 114(36):E7592E7601.

NOGA, E.J. (2000). Fish disease diagnosis and treatment. Iowa, USA: Iowa State University, $321 \mathrm{pp}$.

Noor El Deen, A.E.; Dorgham, S.M.; Hassan, A. H. M. and Hakim, A.S. (2014). Studies on Aeromonas hydrophila in Cultured Oreochromis niloticus at Kafr El Sheikh Governorate, Egypt with Reference to Histopathological Alterations in Some Vital Organs. W.J.F.M.S., 6 (3):233-240

DOI: 10.5829/idosi.wjfms.2014.06.03.83136

Parris, D. J.; Brooker, R. M.; Morgan, M. A.; Dixson, D. L. and Stewart, F. J. (2016). Whole gut microbiome composition of damselfish and cardinalfish before and after reef settlement. Peer J., 4:e2412.

Perera, R. P.; Johnson, S. K.; Collins, M. D. and Lewis, D. H. (1994). Streptococcus iniae associated with mortality of Tilapia nilotica $\times$ T. aurea hybrids. Journal of Aquatic Animal Health, 6(4):335-340.

Rohde, A.; Hammerl, J. A.; Appel, B.; Dieckmann, R. and Al Dahouk, S. (2015). FISHing for bacteria in food-A promising tool for the reliable detection of pathogenic bacteria? Food Microbiology, 46:395-407. 
Samuelsson, O. B.; Nerland, A. H.; Jørgensen, T.; Schrøder, M. B.; Svasand, 1. T. \& Bergh, Q. (2006): Viral and bacterial diseases of Atlantic cod, Gadus morhua L. their prophylaxis and treatment: a review. Dis. Aquat. Org., 71:239- 254.

Spanggaard, B.; Huber, I.; Nielsen, J.; Nielsen, T.; Appel, K. F. and Gram, L. (2000). The microflora of rainbow trout intestine: a comparison of traditional and molecular identification. Aquaculture, 182(1-2):1-15.

Sujatha, K.; Senthilkumar, P.; Sangeeta, S. and Gopalakrishnan, M.D. (2011) Isolation of human pathogenic bacteria in two edible fishes, Priacanthus hamrur and Megalaspis cordyla at Royapuram waters of Chennai, India. Indian $J$. Sci.Technol;4:539-41.

Sylvain, F. E.; Holland, A.; Bouslama, S.; Audet-Gilbert, E.; Lavoie, C.; Val, A. L. and Derome, N. (2020). Fish skin and gut microbiomes show contrasting signatures of host species and habitat. Applied and Environmental Microbiology.

Umoh, U.J. and Odoba, M.B. (1999). Safety and Quality Evaluation of Street Foods Sold in Zaria kuna State, Nigeria. Nigeria Journal, 10:9-14.

Wilkie, M. P. (2002). Ammonia excretion and urea handling by fish gills: present understanding and future research challenges. Journal of experimental zoology, 293(3):284-301.

Yagoub, S. O. (2009). Isolation of Enterobacteriaceae and Pseudomonas spp. from raw fish sold in fish market in Khartoum state. African Journal of Bacteriology Research, 1(7):085-088. 